\title{
Article \\ MUSIC BEYOND SOUNDS AND ITS MAGIC IN THE CLINICAL PROCESS
}

\section{Ruth Lijtmaer ${ }^{1}$}

This paper highlights the role of music in psychic change through a clinical case. A patient, who was initially distant and cold, started to talk about music. An enactment around the analyst's comment about a famous conductor, started an exchange of music "notes" that changed the course of treatment. For the analyst, it brought old memories and musical reveries. For the patient, music allowed him to be in touch with undiscovered parts of himself and losses that had not been mourned. There was a mutual personal transformation and expanding awareness of self and other for both participants.

KEY WORDS: reverie; music; death; transformation; countertransference; unconscious communication

https://doi.org/10.1057/s11231-020-09271-x

\section{OVERTURE: REVERIE [BEGINNING: REVERIE]}

It was a winter afternoon. I was in my office looking out the window. The snow was falling consistently. I started to hear, in my head, Mahler's Adagietto from his Fifth Symphony. In my reverie, I was connecting the music to the beautiful landscape.

But I also thought of Gustav Mahler's (1860-1911) worldview, shaped by poverty, domestic violence, and the deaths of 7 of his 14 siblings (Feder, 1978, 2004; Dimitrijevic, 2007). He witnessed his father beating his mother, a woman trapped in a loveless marriage. He could do nothing but flee to the streets. Later, Mahler was struggling with his health, the early death of his daughter, and his wife Alma's infidelity. He also had a brief

Ruth M. Lijtmaer, Ph. D. is a Senior Supervisor, Training Analyst, and Faculty member at the Center for Psychotherapy and Psychoanalysis of New Jersey. She has a private practice in Ridgewood, New Jersey, and is a Board member of the IFPE.

A short version of this paper was presented at the Conference: The Arts of Time: Relational Psychoanalysis and Forms of Vitality in Clinical Process. IARPP, Rome, Italy, June 9 to June 12, 2016

Address correspondence to Ruth Lijtmaer, Ph. D., 88 West Ridgewood Ave, Ridgewood, NJ 07450, USA. Email: rlijt123@gmail.com 
analysis with Freud before his own death eight months later. I thought of the themes of death and dread, longing and loss, fate and redemption, beauty and suffering, reverberating in myriad and haunting forms in this symphony. Paradoxically, this movement is Mahler's "love letter" to Alma.

All of this was on my mind when my reverie was interrupted, I heard the door of my waiting room. I came back to reality. Paul was here. I thought of my struggles with Paul: I experienced him as cold and distant. I could not reach him emotionally. I frequently felt empty and at times angry that I could not move him from his defensive stance. I wondered if there was something I was not saying that could reach him emotionally.

This paper is my present reconstruction after my reverie of what happened between Paul and me, before and after our talking about music became part of the analysis. I had my reverie about eight months into treatment. And music appeared in the room three months after my reverie. Therefore, this story is told in retrospect. I am describing moments in treatment when treatment was locked and how music opened it and let it blossom.

I use a music metaphor of a symphony and other Italian glossary as headings, to describe the transformations in treatment.

\section{PREFAZIONE [PREFACE]}

In hindsight, I wondered: what provoked and were the seeds of my reverie. I realized how much I struggled with Paul because he spoke in a monotone voice no matter what the topic was. He did not express emotions even though at times I expected those feelings to appear. I felt frustrated that I could not reach him emotionally and we could not get out of that impasse. At that time I did not know how Paul experienced me but I heard a rigidity and distance in him, perhaps the same that he experienced from his wife. I see now that my reverie was my way to protect myself from his coldness, to help me be in a warm place or to warm myself before he came, so that I could hear him better... or, perhaps, to gain some relief, to not be in the cold with him. Was my reverie stimulated by my wish to replace his deadness and coldness with exciting moments, to keep me alive due to what I experienced as his deadness? Was I anticipating death, loss, and mourning? Was this my internal way to prepare myself to see him for the session? Mahler's music was a source of comfort, sheltering and protecting me from the winter cold outside as well as the coldness inside the room.

I can see now that my reverie filled me, in an open, but unpredictable way, both to the past and to the future. I can also see now that the transformations that occurred in Paul and in me were unexpected. 


\section{PRIMA PAROLE [FIRST WORDS]}

My first words are a palette of sounds, as I process through writing, my voyage with music and Paul.

The topic of music spurred my curiosity into what music means to me. For me, music is an emotional experience. At times it is soothing, at other times exciting. Music allows me to get deep inside myself and helps me hear the "other" better. Sometimes it is a way to remove myself from reality. I can imagine how music may sound if I am the conductor or the performer of that piece. Like a proactive dance, I want to move my body not only in response to music but in anticipation of it.

Looking backwards, I wonder how my love of music and my own history of loss of my country and loved objects, made me more attuned to Paul's unspoken music. His and my connection to music added an unexpected and ethic dimension to the process of treatment.

The memory of my grandmother came to my mind. She died when I was 10. However, I always remember going to visit her and classical music, particularly opera, was in the background. I wonder now if that was when my love for classical music started. I also speculate now that I was also identifying with Mahler's losses ${ }^{2}$ (Feder, 2004; Dimitrijevic, 2007), even though the piece of music in my reverie is about love. I realized later the parallels between Paul's losses and mine.

\section{PRIMO MOVIMENTO: ESPOSIZIONE CON CADENZA [FIRST MOVEMENT: EXPOSITION AND IMPROVISED SOLO PASSAGE]}

Paul is a middle-aged, married man who came to see me because he was unhappy in his marriage. He felt his wife was cold and distant. In his professional life, he was not happy either, because the company would not acknowledge his efforts to do the best possible work. He also had very few social relationships.

Paul's mother died when he was 6 years old after suffering with cancer for the previous two years. His memory of his mother was fuzzy. He only remembered that she had been affectionate and he recollected the sadness and somber mood of the house during that time.

I can see now how the coldness and distance in Paul's emotions reproduced in treatment the loss and death of his mother. This important death was recounted to me in a non-emotional way.

I sensed that his mother had become distant and withdrawn due to her illness. For two years Paul's mother was "disappearing." I imagine that he was carrying death experiencing his mother in this way. I also think of the degree of trauma he suffered as a child and thought of Mahler's losses and 
traumas. However, it is not clear if this was a constructive memory or his fantasy about her. He spoke of this memory of his mother in a nonemotional tone. I wondered if he was unable to mourn. This fact was a mystery to me and I was unable to pursue more of it since as he said he did not remember more. Was Mahler's Funeral March in the first movement of this symphony, Mahler's way to mourn his losses? Was his Addagietto motivated by love but also by fear of experiencing another loss? Am I confusing Paul with Mahler? I am thinking again about my reverie and how my reverie helped me find Paul, and be found by him-Paul's losses and my own, our shared susceptibility.

\section{PROSEGUIRE LA CADENZA [CONTINUE THE CADENCE]}

Initially we talked about his losses, his mother's death and how it was for him as a young child. Since his father's death some years ago, he had not been in touch with his stepmother who had been a source of support for him and had introduced him to music. They continued sharing music together from then on. Paul's stepmother died during his treatment, but I cannot remember exactly when I learned about it. I guess it was probably after he started to talk about music. However, I felt strongly that we shared an unconscious communication about music even before it became a verbal means of communication. It was a deep feeling that I had not felt with him before.

When his stepmother died he started to feel guilty for not having been there with her more, the way she had been with him. Memories of their listening to music together came back to him. But he told me about these things in a flat tone and distant manner. I discovered later in treatment that Paul's stepmother had introduced him to music the same way my grandmother had done with me. There were "music" ties between us that were unconscious at that time.

I got the impression that Paul was bringing his dying object/s to the sessions, to me, to be repaired. I started to sense how he carried his dead mother/s inside. I thought of Mahler and the deaths he suffered as a child and then as an adult ${ }^{3}$ (Dimitrijevic, 2007; Feder, 1978). Was Mahler able to mourn his losses? Or was his mourning, as in Paul's case, never fully resolved?

I wonder if Paul's guilt about not mourning his mother and stepmother was expressed in his defensive stance manifested by his apparent coldness, in his "psychic retreat" (Steiner, 1993). I also wondered if his starting to talk about music was a way of showing off to "mother" so that mother could see how clever he was. I experienced this as his way to connect with me as a 
child, longing for his relationships with his mother and stepmother, but also as an adult, being able to share his deepest feelings with a peer. Adult and child are immersed in each other. If music was his way of impressing me, was he performing or was there a longing to express something very dear to him? Or were both processes going on? Was he competing with his father for his stepmother's love? Themes of betrayal, Alma and Mahler (Feder, 2004), Paul and me, death and loss, colored our interactions. The musical communication was still an unconscious process at that time.

\section{SECONDO MOVIMENTO: ADAGGIO MOLTO APPASIONATO [SECOND MOVEMENT: ADAGGIO VERY PASSIONATE]}

Paul frequently talked about his inner isolation and loneliness. Even though he was "social" (i.e., talks to people about current events, art, and politics) he did not feel emotionally connected with many people. Talking about this, in one session about three months after my reverie childhood musical memories came up. He talked about feeling like a bore in high school not only because of his love of classical music, but also because of the painful memories of feeling that he had to hide his love of music from his classmates, who bullied him about it: "After all it was classical music, not rock." This was why he kept his love of music a secret, so that he would not be shamed, teased, or laughed at.

Paul told me that he had recently started attending musical events and would tell me what music he heard. His voice had an emotional tone that I had not heard before.

That first time that Paul talked about music was a very special moment for me. I began to feel connected to him and heard him in a different key. I wonder if through my reverie I picked up something unconscious in him related to more intense emotions. This was an enigma, and the enigma was music: we started to use music for our psychological work. I recognized this as an important moment in his treatment because I noticed that my own internal state changed along with his.

I wondered how I could help him to make analytic contact with this aspect of himself. I suggested that his love of music might have something to do with his relationship with his stepmother with whom he had been so close. Even though Paul said he was not sure about that connection, there was something in his voice that made me think that something was at work. His tone was softer but alive, which allowed me to bond with him in a different way, taking away the dread of his deadness. It felt like an invitation to go inside, to pass through a door that had been closed before. 
I thought again about my reverie and wondered if it was also anticipating his need for emotional connection with others.

Paul also shared his good memories of his stepmother listening to music with him, not with her own sons, who were much older than him and were out of the house. Besides, they did not like classical music. This made me think of my own experiences with my grandmother, and listening to classical music with her in her home. We both had similar experiences in our childhoods with a caring adult.

I started to keep my ears open to be able to hear parts of him that I had not heard before. I was curious and moved by his stories. However, as music became more audible in his material, it brought conflict in me: what did it mean that he was sharing this with me? Was he looking for approval and/or a connection? If I spoke about music, would that turn him off and would he revert to his monotone voice?

\section{TERZO MOVIMENTO: MOLTO AGITATO E PESANTE [THIRD MOVEMENT: VERY AGITATED AND HEAVY]}

Music was in the room with us and it became a symbolic structure with different layers of experience. In a session, two months after he started to talk about music, and after my reverie, I took a risk and intervened. Paul was speaking about a recording of a renowned German conductor. Something inside told me to respond. I cannot tell now if that urge was based on my need to be "heard," a need for a deeper connection, or a desire to use my knowledge of music to change his emotional stance. I asked him if he knew that this conductor supported the Third Reich. He was astonished by my intervention since he did not know that I liked classical music and that I knew this fact. ${ }^{4}$

As I spoke, I felt very involved; my voice was a little shaky. My language became more provocative and enigmatic, and this had started with a surprising experience (my talking about the conductor). Perhaps my intervention allowed him to feel less alone in the lonely world that he had created for himself and helped him to transform what was dead into something alive again through language.

My statement about the conductor was a historical statement that eventually became more personal as time went on. However, I can now see that I was giving him a mixed message: he was an extraordinary conductor but he was shrouded in death. Was I influenced by the fact that I was writing a paper on intergenerational transmission of trauma at that time? Did that writing stimulate me and influence me to tell him this? Or was I trying to shake him up to make him alive? As I think back, it was probably all of the 
above. Over time that association about music became both more personal and emotional.

I can see now that my internal experience (my shaky voice) started a process of opening up the relationship. I was trying to connect with him so that we could "be" together. I showed him a part of myself including my emotional reaction. I realize, now, that through my "enactment" I was trying to become at one with the psychic reality of that moment (Atlas \& Aron, 2018). I also realized that talking about music was a way to get "inside" of him and of me. I recognize now that I became more alive as he was becoming more alive himself. This process of transformation was aided by the process of concordant identification (Racker, 1957), in that Paul was picking up some music notations from me, by my tone of voice, which resulted in bringing warmth to the room.

I wonder now, what made me make that statement? I was also shocked that I had blurted it out. As I write now, I wonder if my saying it was perhaps my unconscious wish to get "inside" Paul. Paul was cold, the conductor I mentioned was cold, his wife was cold, and I was trying to get warm. I remember feeling trapped by his deadness. I felt I was at the mercy of his projection. My talking about the conductor can be described as follows: I have an association. I make a conscious decision to say something that can reveal something about me. This alters his experience of me. I alter the frame. There is now a consent to change the frame, now we can talk openly about music. Despite this, when that happened, I was still not sure if talking about music was as helpful as "I" wanted it to be-if it would allow us to emotionally connect better.

I also remember that I had read an article about this conductor's involvement with the Third Reich a few days before I saw Paul. Was I hearing more of Paul's losses? Was Mahler on my mind? I realize that I started to hear in a "pianissimo" mode themes of love and death, closeness and distancing, linking and estrangement, bonding and isolation. Not with words, but with sounds, rhythms, cadences, and with Mahler in my head. On one hand, I was trying to produce a link with his musical part, a part that I felt I could not often reach. On the other hand, I was perhaps shaming him for not knowing what I knew about the conductor. My conflict with Paul was how much to push. I can see now that my unpredictable, enigmatic response was my unconscious attempt to reach him. This was a better way to touch him than a direct interpretation but I did not know that when I spoke of the conductor. My statement was an unpredictable and multiple determined way for me to reach him.

This leads me to my reverie, again, which went backwards and forwards in time. Initially, I dreaded seeing him, later, our talking about music lead me to look forward to our sessions. 
I thought of his emotional connection to his mother and how she had died when he was young; and the love of his stepmother, who introduced him to music, and whom he had also lost. Was his defensive position of detachment an aspect of shame because he was afraid of "being seen?"

Paul's emotional detachment may relate to an underlying sense of shame in expressing his passions more openly. His fear of being ridiculed, as he had been in his adolescent years, came to my mind. I also thought of the shame he might have felt as a child without a mother, different from his classmates. He probably wanted to hide from his peers because of his suffering, and his shame over his loss. Furthermore, I might have shamed him with my intervention about the conductor: I knew something that he should have known. However, Paul stated that my revelation about the conductor allowed him to see another part of me. I realize now that he saw me because I was seeing him. The introduction of music opened the treatment and started a process of transformation on both sides and in both directions. I wonder if it might not also have been a wish to be seen in addition to, or perhaps instead of the shame at being seen.

At that time, I suggested that perhaps music was an image of life that he had experienced during childhood and sometimes continued to live out today but in a more hidden way: his life was boring (the boredom he spoke of at the beginning of the analysis), he lived in solitude. Music had value only inasmuch as it was preserved in the past, something he could not face in the vitality of emotions of the "here and now." I also wondered if he also saw another part of himself and the secret love of music that were coming out.

\section{QUARTO MOVIMENTO: ANDANTE CON AFFETTO [FOURTH MOVEMENT: FLOWING WITH FOND EMOTIONS]}

After that first time, Paul continued to talk about music again and again. Was he looking for my recognition of him. Was he showing me how musically educated he was? Once, Paul told me that at times there was a melody in his mind that would not go away. I wondered aloud if he kept that sound with him so that he would not have to face his reality or if he was defending himself from expressing more feelings to others. I also thought of music as a transitional object, as a comforting experience. At that time, like Paul, I would also think of certain pieces that I play in my head, which give me comfort and also excitement. I wondered again if it were me who was in his head becoming the transitional object. I thought of Mahler again what music did to him and to me. Mahler had a history of trauma, so did Paul and I. I also know something about oppression and danger (my immigration 
[Lijtmaer, 2017], the conductor?). I wanted Paul to see me. Even though in my reverie, I recalled a music of love, the first movement is a funeral march. I consider that my preoccupation with Paul related to whether he was able to mourn and whether treatment was helping him to do the work of mourning.

For Mahler, as well as for both of us, music had the magic to take us to an ethereal place where we could connect with deeper parts of ourselves. There was also the theme of love and death. Initially I was not aware of it. Later on, it moved from ghostly, to more concrete in the sessions; relating to the loss of his dear ones, my loses, and the loss of that part of himself that he was starting to rescue. I wonder now if Paul became aware of my internal experience or our shared experience paralleling conscious and unconscious processes.

I can see, now, that before music started to join us, there was an impasse that we could not get through. I was patient with him waiting for something to happen but nothing did, until music appeared at first as a subtle "pianissimo" that became more "forte" over time. This "ethical position and attitude" (Scarfone, 2013, p. 558) changed our relationship.

Paul started to tell me all the musical secrets that he had not told his wife. He felt as if he was cheating on her. Paul's usage of the word cheating made me think of Mahler again and his relationship with his wife, Alma. She had cheated on him. Something started to happen in the transference and countertransference. Music was involving us in a complex way: erotic, maternal, intellectual, with its different layers.

For Mahler (Feder, 1978; Dimitrijevic, 2007) it was 1910 when he made the devastating discovery that his young wife of eight years, Alma, was being pursued by a persistent suitor who had asked for her hand in marriage. This discovery took its toll on Mahler's weakened heart and precarious psyche, prompting the introverted composer to seek a session with Sigmund Freud. ${ }^{5}$ Mahler died a year later in 1911. Love and death again. I reflected on the evolution of my feelings about Mahler's music. How ambivalent I was about it earlier in my life, yet, recently, I became more involved in it. I think that my own experience of Mahler colored my experience of Paul through my connection with both of them. Music was the vehicle for the development of transference and countertransference emerging in an unexpected way.

\section{INTERVALLO [INTERVAL]}

In this section I will visit the theories that helped me conceptualize the dynamics of our relationship. 


\section{Reverie}

Any narration, seemingly realistic, always tells us as analysts (and only as analysts) of something else: of the patient's internal world and, in particular, if we are able to listen, of the appropriateness of his instruments (for feeling, dreaming, and thinking). Civitarese and Ferro (2013) remind us that we have to put ourselves into a mental state open to the new and unpredictable, and to think of losing ourselves in the field and re-emerging from it. Ogden considers reverie "a principal form of re-presentation of the unconscious (largely intersub-jective) experience of analyst and analysand. The analytic use of reverie is the process by which unconscious experience is made into verbally symbolic metaphors that re-present unconscious aspects of ourselves to ourselves" (Ogden, 1997, p. 727, in Birksted-Breen, 2012, p. 827).

Everything that goes on in the analyst's mind during sessions are considered reveries by Ogden. "He includes all kinds of daydreams and fantasies, not just those that seem to be related to their patients. Even the analysts' physical sensations during sessions are considered to be manifestations of reverie." (Avzaradel, 2011, p. 850). Odgen's work (1994 and 1997, in Avzaradel, 2011) suggests that reverie can be thought of as a maternal function. Mothers receive their babies' communications then metabolize them for their babies. This is similar to Bion's (1967) hypothesis of an alpha function exercised by the mother when she processes the baby's projective identification and converts what he calls "nascent sensory data," including emotional data, or beta elements, into alpha elements (p. 308).

I see now that my reverie, my hearing Paul without words, my losing myself in the field and re-emerging from it, and my impulse to talk about the German conductor, were my ways of saying "I hear you," as my part in the development of the analytic field.

Scarfone (2010) states how the analyst assists the hearing and welcoming the analysand's speech without immediately reducing the latter to an assured "I hear you;" it implies allowing the alien-ness that dwells in that speech to run its course, through the analyst's attempt to depose, if not revoke, his own ego. The analyst's aural offering denotes a disposition in which attention cannot be exclusively paid to signifiers, insofar as the other's speech. Attention is to give way to felt experiences in the analyst, leading to perceptible changes in analytic listening. It is a matter of statesthe states in which the analyst finds himself/herself. The analyst's active part in the reinstatement of the original enigma is therefore doubled up by the analyst's essential passivity-passibility, ${ }^{6}$ through his/her listening disposition. 
My reverie turned out to be a lifesaver for Paul's treatment. While writing this paper, I became aware of the power of music and the enigmatic, unpredictable way that reverie announced the process of transformation.

\section{Frame}

Our symphony was developing, and there was a shift in our relationship that lead us to exit the impasse. The music's themes, its different shades (minor and major) were unfolding like magic. We started to touch the sounds and metaphorically to touch each other.

When I told Paul about the conductor, in a way, I changed the frame and the rules of the analysis. I brought the music (the outside) with my comment about the conductor (part of me) into the frame. I changed the content and moved the frame by sharing my associations, making music part of the frame. This shift in the frame was something like: "Now we can talk about music."

Goldberg (2017) talks about the frame as a living organism that plays an active role in organizing the perception of, and maintaining psychosensory contact with, the world of objects (both physical and external). The analyst's contribution to keeping the frame alive, constantly reconfiguring it according to the demands of the encounter, is a mode of engagement in which the analyst implicitly joins the patient in sensing music together. The qualities of this movable frame are constantly micro-adjusting and becoming something new.

\section{Rottura del Impasse [Breaking the Impasse]}

Harris (2009) considers Aron's (1996) statement that impasse in treatment always has something to do with an impasse in the analyst. She said that in circumstances of impasse, there is always a paradox. Deadness and stasis can seem locked in, and the dyad trapped into, polarized complementarities. But within impasse there is always the potential for the use of an object, for a weathering of destructiveness, or a slight shift in the psychic equilibrium of one or both participants. Deadness and a point of optimal turbulence are actually closer than one might imagine. Looking back, I can see now that my contribution in breaking the impasse had to do with my strong need to connect emotionally with the death inside of Paul. The aliveness of music became the vehicle by which we could both begin to mourn the dead and recover from the deadlock of the impasse.

As I write about my surprising intervention regarding the German conductor, I think it was my unconscious way of encouraging Paul to express his hidden feelings in words. This thought lead me to Levine (2008) 
who asked: "How do we determine, moment to moment within the session, when we may 'analyze as usual' as opposed to when we should wait for the inspired moment of formal regression that will unconsciously and spontaneously allow us to perform "the work of figurability?" (p. 646). I cannot fully answer that question but I can think of my need to bond with Paul and help him verbalize his inner world as one reason for impulsively sharing that information with him. At that time, I also remembered going to visit my grandmother who was listening to classical music. This was a memory that I had not had for a long time. I realized that even though I knew that classical music was an intrinsic part of me, those feelings became more vivid and alive in my relationship with Paul. I remembered my grandmother, Paul remembered his stepmother, both memories were associated with music. For both of us, music is a soothing experience, in Paul's unconscious and mine. Music also allowed us to remember. We had a "meeting of minds" (Aron, 1996) in that two separate subjectivities allowed the emergence of a third, here was music, an intersubjective field of emerging experience.

I also thought of Stern's et al. (1998, in Civitarese, 2019) "moments of meeting" or what Bion calls moments "at-one-ment" (1967). Bion proposes, based on the model of the mother-child relationship, to consider the shared emotion of the session as the first element for aesthetic growth of the mind. Mother and child understand each other perfectly even when the latter cannot yet speak. Clearly between the two there is a communication system based on the intensity of exchanges, their duration, and nonverbal language. More specifically, the event that promotes psychic growth is the emotional at-one-ment.

\section{Comunicazione Non Verbale [Non-Verbal Communication]}

Reflecting on the musical connection between mother and child, Trevarthen (2009) observed that communication with a newborn can be mediated in silence, but it is always moving and rhythmic, and the sense of hearing leads and enriches what is seen. The mother has a powerful intuitive feeling for what the baby will respond to, and soon she finds the right pitch and quality of voice. Her infant directed speech is a message of affection and respect for the infant's feelings, and the infant attends preferentially to the loving qualities of her message. As time went on, my accent and the rhythmic ways in which we started to move in the sessions allowed Paul to hear me as a reliable mother. I now believe that this transference allowed him to start the mourning process with somebody who was not leaving him. However, different elements that appeared later in the transference (fear of losing me) indicated that I might not have been such a safe object. The shared music connected us in a special (dangerous?) way. 


\section{Oggetti Morti e Vivi [Dead and Alive Objects]}

For Baranger (2009) unmourned dead/alive objects crowd out the vitality of internal object life and produce bastions of resistance to growth. This is particularly likely in situations of trauma. Baranger's idea of dead/alive objects reminded me of Green's (1986) concept of the "dead mother." Green described an infant's reactions to the emotional withdrawal of the mother due to depression. The mother's abrupt detachment from her infant, is experienced by the child as a catastrophe; because without any warning signal, love has been lost in one blow. This carries in its wake, besides the loss of love, "the loss of meaning" (p. 150). According to Green, after failed efforts at repair and reunion, the child will both withdraw emotionally and identify with the mother's blankness, becoming her mirror image, meeting absence with absence as the only way to connect with her. Green advised the therapist to: (1) think of his/her work as providing a transitional space; (2) maintain an aliveness and vitality that the patient can internalize; and (3) consciously avoid being a dead object, so that ultimately, this may help the patient mourn his/her early losses. In these ways, Green underscores a major conflict that prevents one from mourning: the requisite transition from living with absence, to being present and living with loss (Green, 1986, in Rubinfine, 2016). Actually, at times, I felt that I had to bring Paul to life.

Stein (2004) with the notion that denial or similar defense mechanisms are prototypical components of the mourning process, suggests that music can be thought to function as an object of transitory identification, in that the aesthetic reverie evoked by listening to it implements a fantasy in which the painful reality of loss is denied or disavowed.

Deutsch's explanation for the lack of mourning is that children can display a "heartless" response following the death of a loved one because "the ego of the child is not sufficiently developed to bear the strain of the work of mourning and ... therefore utilizes some mechanism of narcissistic self-protection to circumvent the process" (Deutsch, 1937, quoted in Stein, 2004, p. 796). The most extreme expression of these mechanisms is the omission of affect. Perhaps this may explain why Paul was emotionally detached.

\section{Vita e Morte [Life and Death]. Anch'io Sono Diventato Vivo [I Became Alive Too]}

Thinking of how Paul and I became alive when talking about music lead me to Odgen and Odgen (2012) who illustrate the centrality of the experiences of aliveness and deadness to the analytic process, and demonstrate how the quality of aliveness - an aliveness of language, of self-awareness, of waking 
dreaming, of conscious thinking and feeling-is, from a certain point of view, a goal of analysis.

Qualities of aliveness and deadness are qualities of self-experience that not only include the nature of the interplay of conscious and unconscious aspects of mind but also encompass a great many other facets of an individual's experience, for example, qualities of imaginative thinking, dreaming, falling in love, of "getting lost" and "being found" in the course of conversation with a friend or with one's analyst (Ogden \& Ogden, 2012, p. 251).

\section{Altri Pensieri [Other Thoughts]}

(a) Atlas and Aron (2018) state that we unconsciously "look forward" (p. 22) to future possibilities as the mind anticipates, prepares, shapes, and constructs. They underscore "how our unconscious hopes and dreams, our goals and ends, pull us towards our destiny and how we unconsciously anticipate and dramatically rehearse for that future" (p. 22). I wonder if Paul was looking into the future in a more optimistic light in view of his selfdiscoveries.

(b) Thinking about Mahler and Paul, I came to acknowledge that Mahler was the third in our interactions. Gerson (2004) views thirdness as a recognition that is not first constituted by verbal speech; rather, it begins with the early nonverbal experience of sharing a pattern, a dance, with another person that presents itself in the earliest exchange of gestures between mother and child, in the relationship that has been called oneness. With Paul, I felt as if we both had Mahler in the sessions with us. Not only his music, but all three of our losses: Mahler's, Paul's, and mine. We had all struggled with close relationships, death, and fear of loss.

(c) Steiner (1993) describes patients who are in "psychic retreat," with such a defensive structure that the ability to achieve contact can be very difficult. This defensiveness is constructed in an attempt to avoid intolerable anxiety and unbearable pain. The patient who has hidden himself in retreat often dreads emerging from it because it exposes him to anxieties and suffering which is precisely what had led him to deploy this defense in the first place. I think that shame had also played a role in Paul's "psychic retreat." Steiner (2015) talks about how recognizing shame, may help the analyst support his patients' capacities to tolerate the discomfort of being seen so that the conflicts about seeing can be worked through. I wonder if Paul's guilt (internal bad object) over not mourning his mother and stepmother was expressed in his defensive stance manifested by his apparent coldness and distance. 
(d) Civitarese \& Ferro (2013, p. 195) point out that "the field is delimited; it is a container. As such it is in a dialectical relationship with what is outside it that is with other, broader containers (social groups, institutions, ideologies, etc.)." Like the bow of a violin, our exchanges moved up, down, sideways, transforming us and transforming the field. The sounds came also from a place of vulnerability. For Paul it was his initial tentative verbalizations about music. On my part, it was my cautiousness and wish to connect with him. At the same time, music was a place of pleasure. This shared experience of music dissolved the distance that he had created at the beginning of treatment. I started to become the loving stepmother. By transforming me into her, I realized that my reverie had announced (without my knowing it at the time), themes of sexuality and seductiveness, transference and countertransference, that became elaborated allowing both of our transformations to take place.

It is not at all clear what was said that lead him to take the risk and start talking about music. Nor is it clear what he sensed in and about me. That question is not resolved. I look back and perhaps it was my body language that indicated that I was interested. I also remember that in our initial session he commented on my accent (music again? sound?) and he told me that he felt it was charming. Our music started then, without my realizing it. These waves of rhythmic, tonal, and lyrical patterning, evoking emotional responses, sometimes subtle, sometimes powerful, started to become part of the sessions when Paul invited music to be with us. What seemed like deadness of absence was transformed in deadness of mourning and becoming alive.

(e) Bion's understanding of unmentalized experience, and the Botellas' (2005, in Levine 2008) work on the symbolization of experience and mental states without representation, describe the symbolic experience as potential that has not yet been actualized in symbolic form. Ferro (2009, in Stern, 2013) describes the creation of symbolic experience as transformation. The Botellas call it "the work of psychic figurability," (Kirschner, 2007, p. 303; and Stern, 2013) and referred to it as the process of formulating experience since words construct the experience that has not been articulated before. Unconscious communication progresses from unconscious perception to figurability and reverie. Empathy is the condition of unconscious communication in the analytic pair, according to Bandeira (2017).

Eshel (2012) reminds us that:

Patient and analyst thereby forge a deep experiential-emotional...process where-by the analyst interconnects psychically with the patient, and they become a new, two-in-one entity that goes beyond the confines of their separate subjectivities and the simple summation of the two, an entity (unit or being) of 
interconnectedness ...that transcends the duality of patient and analyst: two-inoneness (p. 151).

and allows for transformation in analyst and patient. Music being a nonverbal, a primitive form of sensory human connection, the sound in the room allowed for transformation in both of us.

(f) Following Levenson (2017),

To the psychoanalyst, the phenomenon of change is as mysterious and elusive as the unicorn. Difficult to describe or define, unpredictable in its moments and forms of appearance, almost impossible to quantify in the hard-data style dear to the hearts of statistical research psychologists, it is nevertheless an article of faith, the very essence and purpose of psychoanalytic effort. Change may follow a formulation of the therapist, sometimes a reactive feeling of the therapist (not necessarily appropriate) (p. 17).

Later on he stated that "Like the mystical or the aesthetic, the psychoanalytic experience is capricious and unreliable" (p. 18). Thinking now about my abrupt intervention, reminded me of Gabriel García Márquez's statement about his writing of his novel Love in the Time of Cholera: "I'm very curious, as I'm writing this book, to see how the characters go on behaving... could almost say that one writes the novel to see how it will turn out" (Márquez, quoted in Simons, 1985, p. 18). Garcia Márquez is telling us that the characters of his book are capricious and fickle, certain responses of the analyst can be too, like in my case. My spontaneous response about the German conductor can be considered in this category of unpredictable interactions. It was sudden, unexpected, and had a jolting sense of having been totally impetuous. As Hoffman (1983, quoted in Stern, 1991, p. 414) stated "The analyst's uncertainty has [...] to do with his inability to know, in advance, how much his own countertransference will govern his response to his patient ...." Odgen (2019) sheds light on this phenomenon by differentiating what he calls epistemological psychoanalysis, having to do with knowing and understanding, and ontological psychoanalysis, having to do with being and becoming. Epistemological psychoanalysis principally involves the work of arriving at understandings of unconscious meaning; by contrast, the goal of ontological psychoanalysis is that of allowing the patient the experience of creatively discovering meaning for himself, and in that state of being, becoming more fully alive (p. 661). He further says that:

...therapeutic action characterizing ontological psychoanalysis involves providing an interpersonal context in which forms of experiencing, states of being, come to life in the analytic relationship that were previously unimaginable by the patient... (p. 667). 
(g) Bion's first models of the mind (1967) were firmly within the scientific and mathematical domain. However, we see him gradually moving away from his preoccupation with science towards an aesthetic explanatory conception of psychoanalytic thought with analogies from the visual arts and literature. Bion stressed that it was the visual sense which lies at the core of unconscious fantasy and he describes more the phenomenology of the analytic encounter in terms of visual and aesthetic analogies. He believed that it is the love of truth, coupled with an aesthetic sense, coupled with the analyst's personality, his training and experience, that are the focus of the analytic encounter (Glover, 1998).

Civitarese (2014) states that great value is given to the intensity of the experience undergone by the analyst and the patient in their encounter. The emphasis on passion as an indispensable dimension of the elements of psychoanalysis, but also on the senses and on the fictional dimension of the analytic setting all serve to concentrate on what is alive in the here and now of treatment. For "passion" Bion means that the analyst must pass through a transformation of his own self, must let himself be impregnated by the patient's suffering -in his terminology become the $\mathrm{O}$ of the patient, or "of the session" (Civitarese, 2014, p. 1077). In this paper, the term aesthetics refers to music with its sounds, cadencies, and verbal and non-verbal expressions. It was through our shared passion for this aesthetic experience that stimulated Paul's treatment to change its course.

\section{CODA}

With music inside both of us, with its sounds, cadences, and rhythm, it was also outside of us in the real world. It was a dyadic experience that was transforming us, inside and outside but also in our interactions. Here the outside is the music that bonds us in this field, in the harmonies of our interactions. Our interactions about music started a process of transformation in both of us in which music was a mutual play of sounds and chords (Knoblauch, 2000, in Betan, 2001). I can describe the music between us like layers in the conductor's score with the staff and notes of each instrument's pitch, which is the fundamental latticework of music notation. It started with my reverie that made me anticipate something about Paul. It followed the dissonant notes of my statement about the conductor as a historical statement. I was conscious then not to be very personal given that I was sharing facts from my anxious place, wondering if it was helpful to bring music in this way. I am not certain now if my anxiety was based on his coldness and how to reach him, not knowing what might happen next. I am 
still not sure if Paul was sensing my anxiety. However, after that intervention our relationship became personal, intimate, and playful.

\section{ULTIME PAROLE [LAST WORDS]}

Our patients come to us with the written scores and notations of their lives. These scores are written in different languages, a large part unconscious. Paul came with his own score and music, which was mute for a while. When music came into the room, our exchanges became more fluid and spontaneous. Paul became more sensitive to other people's needs and was less defended. This was particularly reflected in his relationship with his wife that has since become more intimate and playful.

Paul still feels somewhat awkward in new encounters and is aware that he becomes distant in new social situations. But he continues to talk about his experiences with music and how that part of our relationship helped him be less afraid of expressing his feelings.

Music is a universal language. It is a means to connect with others with or without words. It is a way to express the inexpressible facilitating the emergence of more fluid states of consciousness. Music affords, through its form, greater access to memory, fantasy, and primary process, with sometimes startling emotional insight.

This shared aesthetic experience was the vehicle for the development of transference and countertransference. It may well have been brewing unconsciously for some time before the session in which Paul started to talk about the death of his stepmother.

Each of us had a history of loss and mourning and the shared music talk was the vehicle for psychic transformation in both of us.

This emotional regulation through music in the analytic space emerged in "concert" as Paul and I found one another's rhythms, textures, pitches, and shifting moods that permitted us to compose a special piece, with different cadences in major and minor keys. The magic of music made our musical voices reflect themes of betrayal, love, death, his loses, my loses, and the excitement of what we were creating together. This complex process permitted us to build bridges between his subjectivity and mine, producing our mutual transformation.

\section{ACKNOWLEDGEMENT}

I am deeply grateful to Adrienne Harris and Drew Magidoff for their insightful contributions. 


\section{NOTES}

1. Ruth Lijtmaer is senior supervisor, training analyst and faculty at the Center for Psychotherapy and Psychoanalysis of New Jersey. She is in private practice in Ridgewood, New Jersey. Board member of IFPE from 2015 to the present. She presents papers nationally and internationally. Her latest publications are: (2020). Silenced and Unsilenced: Why didn't they talk before? Otherwise/Uncut, Spring IFPE online journal of the International Forum for Psychoanalytic Education. http://ifpe.wordpress.com/ (2020). Personal reflections on living in the altered state of Covid-19. Clio's Psyche, 27, 1, 97-99; (2020). "Destruction and survival in a dangerous journey". Library of Social Sciences Newsletter, August, newsletter@libraryofsocialscience.com

2. Mahler's extensive losses are described by Stuart Feder $(1978,2004)$. Mahler was an outsider as a Jew among Austrians and a German speaking Austrian among the Czech speaking population in Bohemia, part of the Austrian Empire. His parents were ill suited for each other, the father was a fierce, strong, vital man and the mother a delicate person with a weak heart, from a cultured family. Mahler's childhood was exceedingly painful, he often witnessed his father's physical violence against the mother. The couple eventually had 14 children, but only 6 survived infancy. Mahler was the second born child, after his older brother, Isadore, died in an accident before he turned two. Just after Gustav turned 5 his 2 youngest brothers, Karl, 16 months old, and Rudolph, 6 months old, died 2 months apart. A very painful loss occurred when he was 13 , when he lost his one year younger brother, Ernst, who was tenderly close to Gustav, after a long illness of rheumatic heart disease. Mahler lived in the worlds of both the father and the mother. Like his father, he had incredible energy and a disregard for his fragile physical constitution (he was born with a weak heart too), high intellect, fanatical idealism and inflexible purpose in his work as a conductor and composer, at the same time he lived in the world of the mother too, with significant nervous tension, doubts about himself, an obsession with death and a quest to discover meaning in his life. At age 29 both of his parents died and left him the head of the household of all of his siblings. He survived a nearly fatal medical procedure at age 41 . He had 2 daughters with Alma, and one of them died at age 5 . The year before his death he discovered that his wife was having an affair with Walter Gropius. [Stuart Feder was an MD, psychoanalyst, with a Master's Degree in Music.]

3. In his review of Feder's 2004 book, Dimitrijevic (2007) writes that "Mahler was in a state of endless mourning. ... He was highly sensitive partly because he was a replacement child and witnessed the deaths of several siblings.... Three principal emotional crises of Mahler's later life were all connected with his major artistic achievements. The first took place in the autumn of 1889, at the age of twenty-eight, when Mahler's mother and one of his sisters died within a fortnight. (His father had died in February of that same year.) These losses were followed by the disastrous reception in Budapest of his First Symphony, the first of his orchestral works ever to have been performed. This led to numerous somatic complaints, a surgical operation, and pains that required morphine. ... The overture to the second crisis in Mahler's adult life was an episode of uncontrollable bleeding on the night of February 24, 1901. Mahler was afraid, as were his doctors, that he could have bled to death. Although he had always been surrounded by death, it had never touched him directly. According to Dimitrijevic, Feder analyzes this "multifaceted psychological romance with death" and connects Mahler's feelings of guilt (February being the month when his father died and his 21 year old brother, Otto, committed suicide)" (p. 111). "Then there was the loss of the elder of his two daughters, from scarlet fever at age five, from which Mahler seems never to have fully recovered. In July 1907, at the age of five, Maria Anna ("Putzi"), the object of Mahler's adoration, died of diphtheria in less than two 
weeks. Simultaneously, Mahler was diagnosed with an incurable heart condition-"the unremitting valvular heart disease that stemmed from childhood rheumatic fever" — which felled his mother and one of his sisters and that would eventually lead to his own premature death." "For Mahler to be broken, however, one final blow was needed. During the summer of 1910, Mahler discovered that his wife had been unfaithful with the architect Walter Gropius, and suddenly felt completely desolate" (p. 112).

4. The Nazi quest to purify the German music world from 'degeneracy', and return it to its mythic Germanic-ness-a notoriously indefinable category-motivated an enormous amount of activity, planning, and policy-making. Almost immediately after Hitler was proclaimed Chancellor in January 1933, Nazi supporters, in a continuation of the early activities of the Kampfbund für deutsche Kultur (Combat League for German Culture), began to disrupt musical performances by Jewish artists. There was a ban on Jewish composers like Mendelssohn and Mahler. The only major German figure to offer any sort of public protest was the conductor Wilhelm Furtwängler, who wrote an open letter to Goebbels, strongly denouncing anti-Semitism. But he continued to perform for Hitler (ORT House). Among many other publications, Levi (1994) also examines the climate of antiSemitism, racism, xenophobia, in the world of music and the ambiguous relationship between music and politics in the Nazi Third Reich. As it is well known, there were many examples of Nazi collaboration in psychoanalysis too. Prince (2009) describes that "Where the history of psychoanalysis under Nazi rule in Germany is concerned, it is almost as if one had quite literally obeyed the order: 'You are requested to close the eyes' appearing in one of Freud's dreams. One must not see' (Chasseguet-Smirgel, 1998, p. 1058). With the ascension of the Nazis in 1933, Jews could no longer serve in the administration of medical societies and two members of the Berlin Psychoanalytic group, who would later be identified as confirmed Nazis, Felix Boehm and Carl Muller Braunschweig, with Jones' support, approached Freud for his blessing to take over the control of the institute. Their purported aim was to preserve psychoanalysis in Germany until better times. However, the exclusion of the Jews as part of official Nazi persecution was mirrored by the tacit collaboration by the non-Jewish members who remained. The Berlin Institute would withdraw from the I.P.A. later that year and was absorbed into the Göring Institute where it would contribute ideological support for Nazi crimes against humanity" (Prince, 2009, p. 186).

5. Mahler contacted Freud because of serious relationship problems with his wife Alma, showing among others in potency complaints. Ernest Jones, in his biography of Freud, writes that the two men walked through Leiden, Holland, for four hours [on August 28, 1910, along Academic building, Hortus Botanicus and Rapenburg] in which a sort of psychoanalysis took place. The meeting ended late in the evening. This analytical walking cure worked, because the potency complaints disappeared, and the marital relationship supposedly improved. Unfortunately, Mahler died within the next year, [at age 50]. Although Mahler was totally uninformed about what psychoanalysis was, Freud said never before to have met anyone who understood so quickly what psychoanalysis was about. In the course of the talk Mahler suddenly said that now he understood why his music had always been prevented from achieving the highest rank through the noblest passages, those inspired by the most profound emotions, being spoilt by the intrusion of some commonplace melody. His father, apparently a brutal person, treated his wife very badly, and when Mahler was a young boy there was a specially painful scene between them. It became quite unbearable to the boy, who rushed away from the house. At that moment, however, a hurdy-gurdy in the street was grinding out the popular Viennese air 'Ach, du lieber Augustin'. In Mahler's opinion the conjunction of high tragedy and light amusement was 
from then on inextricably fixed in his mind, and the one mood inevitably brought the other with it (Jones, 1955, pp. 88-89; Maddox, 2006, p. 85).

6. Civitarese (2013) elucidates that entering a state of passivity allows the analyst to be receptive to reveries, to these products of our unconscious psychological world, and to grasp the emotional truth of what is going on unconsciously in the analytic field (p. 618). Further, according to Benjamin and Atlas (2015), "working though the enactment allows the couple to repair the analyst's maternal holding and to modulate the dangerous aspects of passivity [and aggressivity]. The symbolization of these aspects, presented by the patient and considered by the analyst, then become usable by the analytic couple" (p. 59). Passibility captures the analyst's ability for being affected (Scarfone, 2019, p. 573).

\section{REFERENCES}

Aron, L. (1996). A meeting of minds: Mutuality in psychoanalysis. Hillsdale, NJ: The Analytic Press.

Atlas, G. \& Aron, L. (2018). Dramatic dialogues: Contemporary clinical practice. New York, NY: Routledge.

Avzaradel, J. R. (2011). On the construction of thinking. International Journal of Psycho-Analysis, 92(4), 833-858.

Bandeira, L. M. (2017). Unconscious perception and reverie: An intersubjective connection. American Journal of Psychoanalysis, 77, 265-273.

Baranger, W. (2009). The dead-alive: Object structure in mourning and depressive states. In L. G. Fiorini (Ed.), The work of confluence: Listening and interpreting in the psychoanalytic field (pp. 203-216). New York, NY: Routledge.

Benjamin, J. \& Atlas, G. (2015). The 'too muchness' of excitement: Sexuality in light of excess, attachment and affect regulation. International Journal of PsychoAnalysis, 96, 39-63.

Betan, E. J. (2001). [Book Review]. The musical edge of therapeutic dialogue by Steven H. Knoblauch, Hillside: NJ: Analytic Press. 2000. Journal of the American Psychoanalytic Association, 49, 1064-1068.

Bion, W. (1967). A theory of thinking. Second thoughts (pp. 110-119). London: Heinemann.

Birksted-Breen, D. (2012). Taking time: The tempo of psychoanalysis. International Journal of Psycho-Analysis, 93(4), 819-835.

Chasseguet-Smirgel, J. (1988). Les Années Brunes. Psychoanalysis under the third Reich. Journal of the American Psychoanalytic Association, 36, 1059-1066.

Civitarese, G. (2013). Bion's "Evidence" and his theoretical style. Psychoanalytic Quarterly, 82, 615-633.

Civitarese, G. (2014). Bion and the sublime: The origins of an aesthetic paradigm. International Journal of Psycho-Analysis, 95(6), 1059-1086.

Civitarese, G. (2019). Bion's O and his mystical path. Psychoanalytic Dialogues, 29(4), 388-403.

Civitarese, G. \& Ferro, A. (2013). The meaning and use of metaphor in analytic field theory. Psychoanalytic Inquiry, 33, 190-209.

Deutsch, H. (1937). Absence of grief. In The world of emotions: Clinical studies of affects and their expression. C.W. Socarides (Ed.). pp. 73-85. New York: International Universities Press. 1977. 
Dimitrijevic, A. (2007). Book Review. Gustav Mahler: A life in crisis, by Stuart Feder. American Imago, 54, 109-119.

Eshel, O. (2012). A beam of "chimeric" darkness: Presence, interconnectedness, and transformation in the psychoanalytic treatment of a patient convicted of sex offenses. Psychoanalytic Review, 99(2), 149-178.

Feder, S. (1978). Gustav Mahler, dying. International Review of Psychoanalysis, 5, 125-148.

Feder, S. (2004). Gustav Mahler: A life in crisis. New Haven, CT: Yale University Press.

Gerson, S. (2004). The relational unconscious: A core element of intersubjectivity, thirdness and clinical process. Psychoanalytic Quarterly, 73(1), 63-98.

Glover, N. (1998). The legacy of Wilfred Bion. In Psychoanalytic aesthetics: An Introduction to the British School. (pp. 103-136). London: Karnac. 2009.

Goldberg, P. (2017). Reconfiguring the frame as a dynamic structure. In I. Tylim \& A. Harris (Eds.), Reconsidering the moveable frame in psychoanalysis (pp. 92-110). New York: Routledge. 2018

Green, A. (1986). On private madness. London: Karnac Books.

Harris, A. (2009). "You must remember this". Psychoanalytic Dialogues, 19(1), $2-21$.

Jones, E. (1955). Sigmund Freud. Life and work. Volume 2. Years of maturity 1901-1919. London: Hogarth Press.

Kirschner, L. A. (2007). Figuration of the real as an intersubjective process. American Journal of Psychoanalysis, 67, 303-311.

Levenson, E. (2017). A holographic model of psychoanalytic change. In A. Slomowitz (Ed.), The purloined self: Interpersonal perspectives in psychoanalysis. (Chapter 2, pp.16-34). London \& New York: Routledge.

Levi, E. (1994). Music in the Third Reich. New York: St. Martin's Press.

Levine, H. (2008). [Book Review] The work of psychic figurability: Mental states without representation, by César Botella and Sara Botella Hove, England/New York, Brunner-Routledge, 2005. Psychoanalytic Quarterly, 77(2), 639-648.

Lijtmaer, R. (2017). Untold stories and the power of silence in the intergenerational transmission of social trauma. American Journal of Psychoanalysis, 77, 274-284.

Maddox, B. (2006). Freud's wizard. Ernest Jones and the transformation of psychoanalysis. Cambridge, MA: Da Capo Press.

Ogden, T. (1997). Reverie and metaphor: Some thoughts on how I work as a psychoanalyst. International Journal of Psychoanalysis, 78, 719-732.

Ogden, T. (2019). Ontological psychoanalysis or "What do you want to be when you grow up". Psychoanalytic Quarterly, 88(4), 661-684.

Ogden, B. H. \& Ogden, T. H. (2012). How the analyst thinks as clinician and as literary reader. Psychoanalytic Perspectives, 9(2), 243-273.

ORT House, London: Music in the Third Reich. http://holocaustmusic.ort.org/it/ politics-and-propaganda/third-reich/

Prince, R. (2009). Psychoanalysis traumatized: The legacy of the Holocaust. American Journal of Psychoanalysis, 69, 179-194.

Racker, H. (1957). The meanings and uses of countertransference. Psychoanalytic Quarterly, 26(3), 303-357.

Rubinfine, P. (2016). In the pursuit of absence: Reimagining early loss within the psychotherapy relationship. Psychoanalytic Dialogues, 26(5), 549-563.

Scarfone, D. (2010). In the hollow of transference: The analyst's position between activity and passivity. Sitegeist, 4, 1-10. 
Scarfone, D. (2013). A brief introduction to the work of Jean Laplanche. International Journal of Psychoanalysis, 94, 545-566.

Scarfone, D. (2019). The feminine, the analyst and the child theorist. International Journal of Psychoanalysis, 100, 567-575.

Simons, M. (1985). Love and age: A talk with Garcia Márquez. The New York Times Book Review. April 7, 1985 (pp. 18-19).

Stein, A. (2004). Music, mourning, and consolation. Journal of the American Psychoanalytic Association, 52(3), 783-811.

Steiner, J. (1993). Psychic retreats: Pathological organizations in psychotic, neurotic and borderline patients (The New Library of Psychoanalysis, Vol. 19). New York: Routledge. 1996.

Steiner, J. (2015). Seeing and being seen: Shame in the clinical situation. International Journal of Psycho-Analysis, 96(6), 1589-1601.

Stern, D. B. (1991). A philosophy for the embedded analyst-Gadamer's hermeneutics and the social paradigm of psychoanalysis. Contemporary Psychoanalysis, 27, 51-80.

Stern, D. B. (2013). Field theory in psychoanalysis, Part 2: Bionian Field theory and contemporary Interpersonal/Relational psychoanalysis. Psychoanalytic Dialogues, 23, 630-645.

Stern, D. N., Sander, L. W., Nahum, J. P., Harrison, A. M., Lyons-Ruth, K., Morgan, A. C., Bruschweiler-Stern, N. \& Tronick, E. Z. [The Process of Change Study Group]. (1998). Non-interpretive mechanisms in psychoanalytic therapy: The "something more" than interpretation. International Journal of Psychoanalysis, $79,903-921$.

Trevarthen, C. (2009). The intersubjective psychobiology of human meaning: Learning of culture depends on interest for co-operative practical work-and affection for the joyful art of good company. Psychoanalytic Dialogues., 19(5), 507-518.

Publisher's Note Springer Nature remains neutral with regard to jurisdictional claims in published maps and institutional affiliations. 